\title{
Interrogative Utterances as Discursive Strategy in Legislative Interactional Discourse
}

\author{
Lekan Oyeleye $^{1} \&$ Ayo Ayodele $^{2}$ \\ ${ }^{1}$ University of Ibadan, Ibadan, Nigeria \\ ${ }^{2}$ Department of English, Lagos State University, Lagos, Nigeria \\ Correspondence: Lekan Oyeleye, University of Ibadan, Ibadan, Nigeria. E-mail: oyeleye1@yahoo.com
}

Received: August 2, 2012

Accepted: September 1, 2012 Online Published: September 26, 2012

doi:10.5539/ijel.v2n5p122

URL: http://dx.doi.org/10.5539/ijel.v2n5p122

\begin{abstract}
This paper examines the discourse function of interrogative utterances in legislative interactional discourse (LID). Texts of legislative sessions of the Lagos and Ogun State Houses of Assembly in Nigeria were purposively sampled and analysed using insights from speech acts, conversation analysis and systemic functional linguistics. The analysis reveals that interrogatives in legislative interactional discourse serve two broad discursive purposes of elicitation and directive which enhance propositional development and coherence. Categories of interrogative utterances with elicitation function include elicit-inform, elicit-clarify, elicit-confirm, elicit-agree and elicit-permit. Interrogative directive utterances deployed almost exclusively by the Speaker serve as a turn allocation cue prompting other legislators' verbal or action response. It is further revealed that, structurally, these directives are expressed as one of the forms May + request, wh-clauses and subject-operator invertednominal phrases. When skilfully deployed by legislators, these interrogative utterances enhance interactional success and improve the process and product of law making and governance in Nigeria.
\end{abstract}

Keywords: interrogative utterances, speech acts, elicitation, directive, legislators

\section{Introduction}

Discourse practices within the legislature have come under the scrutiny of discourse analysts in recent times. While some of these studies have examined discourse markers (Ayoola, 2008), argumentation structures (e.g. Ilie, 2000), and discursive structure of interruptions (Carbo, 1992), others have taken a more critical discourse approach focusing on issues of contextualization (e.g. Van Dijk, 2003, 2004) and ideology (e.g. Van Dijk, 2000; Steiner, 2004). In addition to these studies, Chilton (2004) examined the nature of questioning in parliamentary discourse. The study, however, has not given attention to the discourse function of the interrogative utterances as a strategy for achieving structural progression and propositional coherence in legislative interactional discourse (LID).

This paper sets out to investigate the discourse function of interrogative utterances as a discursive strategy in LID against the backdrop of the interactive and argumentative nature of debates in the legislature which is yet to be significantly explored in the literature on political discourse and conversation analysis.

A study of how interrogative utterances are used in legislative discourse is capable of demonstrating propositional coherence and the interactive frames of agreement and disagreement in deliberative politics which can be developed as a tool for law making and governance in Nigeria.

\section{Legislative Interactional Discourse in Nigeria}

Legislative discourse is a sub-genre of political discourse. Broadly speaking, the objectives that legislative discourse aims to satisfy are to legitimate or contest legislation, to represent diverse interests, to scrutinize the activity of government, to influence opinion and to recruit and promote political actors. (Dijk, 2003, 2004) In other words, legislative discourse is primarily involved with the exchange of information or knowledge that will ultimately enhance the process of law making and governance. Thus, the activity of legislatures rests largely on the linguistic performance of the participants (legislators) who produce talk and texts (Chilton, 2004; Mey, 2001; Steiner, 2004). Obviously, in carrying out their constitutional responsibilities, legislators must perform 
appropriate linguistic acts, in a preordained sequence, and within the context of the procedural expectations of legislative sittings. Though primarily spoken, LID exhibits structures that cut across boundaries of speech and writing.

Legislators perform linguistic acts that are reflective of their political role as law makers and politicians. The linguistic act represents the function of a speaker's utterance in discourse. Here "function" can be understood as relating to either the interactional or propositional roles of utterances in discourse. For instance, in the process of enacting laws, legislators may solicit, make submissions, pass resolution, etc. While function, on the one hand, may refer to sequential relationships between utterances in discourse in the way they initiate or respond to other utterances, it may, on the other hand, mean the act performed by an utterance, its illocutionary force, where a distinction is made between "what is said" and "what is done". There, however, exists a correspondence between these discourse moves and more specific acts. For instance, the initiation move may correspond to eliciting, directing and informing acts, whose initial function is to request a verbal response, to require a non-verbal response and to provide new information. (Sinclair, 1972)

\section{Interrogative Utterances as Speech Act}

Generally, a speech act is an utterance that serves a variety of functions in communication. The identification of the particular function of the speech act which an utterance has is essential to its being understood in the manner intended by the speaker. In other words, an act of communication is successful to the extent that it is taken as intended or understood as producing what Austin (1962) referred to as uptake.

Over the years, analysts have treated interrogatives as illocutionary acts (Lyons, 1977); as a kind of request or directive (Burton, 1980); as a semantic category (Quirk et al., 1972); and as a discourse category (Chilton, 2004). However, Huddleston (1976: 130) underscores the dynamism underlying the form and content of interrogatives. He argues that "the illocutionary force of an utterance depends on a variety of contextual factors, such as the beliefs, assumption, intentions of speakers and their relative social statuses, which will not always be expressed in the grammatical structure of the sentence uttered." In other words, an utterance, for example, which has an interrogative structure, can be used to give a command or an instruction, express a wish or perform various other functions, when used in an appropriate context.

In the investigation of parliamentary question-asking, Erskine May (1989) cited in Chilton (2004) reveals that the role of questioning in legislative discourse goes beyond being a mere request for information or action; questions are invested with discursive roles which include the structuring of talk exchanges particularly in initiating turns and enabling repair. In this paper, however, questions are conceived as a functional discourse category. This perspective derives from Tsui's (1992) position that questions cannot simply be subsumed under either "request" or "directives": she argues that utterances which elicit solely a verbal response should be referred to as "Elicitations", a term first used by Sinclair and Coulthard (1975). Generally speaking, questions are conceived as information-seeking or action-seeking structures. Balogun (2011:45) argues that "the ultimate goal of an interrogative clause is to seek for information from the hearer, to clarify some doubts or to get a confirmation or a denial of a particular fact where there is any."

Apart from their role in propositional development, questions also often have discursive roles as turn-allocation cues in legislative discourse. Questions are also central to the information processing function of the legislature: members of the House need all relevant information that will assist their deliberations and help the House to arrive at informed conclusions preparatory to the creation of laws.

In LID interrogative utterances as elicitation can be categorized in terms of the nature of the responses which they anticipate: information-seeking questions; action-seeking questions. An elicitation is an act which requests an obligatory linguistic response (information) or its non-verbal equivalent (action) (Sinclair, 1975). While not disputing Sinclair's position, it must be stressed that interrogative utterances requesting for information carry propositional content that are quite different from those requesting for action. Saddock (1974) is of the opinion that requests can take sentence adverbial "please" while there are many types of questions that can be used as indirect requests with which "please" cannot occur. For example, "*Don't you think you should please shut the door?" It is further argued that true questions would allow the pre-tag "tell me" but requests will not. Similarly, Lyons (1977) points out that questions are not a kind of request because "No" in response to yes/no questions such as "Is the door open" is an answer to the question whereas "No" to "Open the door please" is refusing to do what is requested. Other categories of questions include the wh-questions which usually appear to have syntactic constraints with their adjacent utterances. For instance, a where-interrogative would normally have preference for a place adverbial, just as a when-interrogative must be followed by a time adverbial. Notwithstanding the 
syntactic form, a wh-question sets up a propositional frame which has one variable. Any following utterance therefore is pre-classified to provide a value for the variable.

In a detailed taxonomical classification of each type of illocutionary act on the basis of the type of attitude expressed by the speaker, Bach and Harnish (1979) cited in Jakobovits (1969) classified "asking" as a directive. In ideologically-oriented investigation of the act of questioning, Balogun (2011: 47) believes that interrogative utterances "give a strong indication of class and power in society." This, he claims, can be seen in the various ways by which the powerful exercise power over the powerless.

\section{Method of Analysis}

The data for this study consist of the legislative sessions of the Lagos and Ogun States Houses of Assembly in Nigeria. The selected legislative sessions of the Houses of Assembly covering the period spanning the 2003/2004, 2004/2005 and 2005/2006 legislative years were observed and electronically recorded to provide reliable information on the discourse practices in the legislature. Within the period, a total of fifty (50) sessions (of both plenary and committee sessions of the whole House) were observed. Of this number, thirty (30) sessions were randomly selected for recording.

The texts were analysed, using insights from the literature on speech acts, conversation analysis and systemic functional grammar. The functional classification of utterances adopted in this work, as is generally applicable in conversation analysis, rests on Austin's speech acts (1962) framework. The underlying assumption of the framework is that utterances perform communicative functions that are totally not predetermined by the linguistic forms that carry them. However, the function of utterances in discourse (particularly of the debate type) cannot be determined in isolation from its sequential placement in the micro context of the text. Consistent with this view, the starting point of our description of discourse function is the act (the smallest unit of analysis). The theoretical and descriptive framework offered by Systemic Functional Linguistics has demonstrated a clear commitment to the analysis of political texts. Though with a primary concern for the theoretical modelling of language rather than with discourse analysis, the analytical tools developed by its proponents have demonstrated the capability for handling the complexity of political language analysis (see, for example, Martin \& Rose, 2003).

\section{Functional Classification of Interrogative Utterances in LID}

Interrogative utterances in LID can generally be classified into two broad functional categories; elicitation and directive. When used as elicitation, interrogative utterances are information-seeking. Interrogative utterances that elicit information in LID can be classified on the basis of the verbal responses which the questions prospect; among the various responses are inform, clarify, and confirm. On the other hand, as directives, they are action-seeking.

\subsection{Elicit-inform Interrogative Utterances}

The elicit-inform question invites the addressee to supply a piece of information that is unknown to the speaker. The responses therefore cannot possibly realize a confirmation or disconfirmation of the speaker's non-existent assumptions. For example, while contributing to a motion, the Chairman of the Committee of the whole House asked the following question (utterance 1);

Chairman: Honorable member for Alim 2, what is your suggestion as it relates to the issue of the Permanent Secretary? (1)

Member: If the Permanent Secretary is brought to book it will serve as a lesson to others. If they were to take N6 million per month why did they pay them N10 million and for how long? So if the Chairman embezzled N3 million, are we sure that he is not getting back to the permanent secretary? So, they are all the same. (2)

The Chairman's question in utterance 1 seeks information that is yet unknown to the House. What is perhaps clear is that the honorable member has a suggestion; but until he makes that suggestion nobody knows what it is. Similarly, it is only in retrospect (after the information has been given) that it could be determined whether the Speaker or any other member already had the information or not. Prior to that, the Speaker's question would be prospectively classified as elicit-inform. Such categories of questions are usually asked by the Speaker as a way of getting information from a current speaker or any other member in the course of deliberations over issues that have been brought to the floor of the House. On the other hand, the Speaker's question could assume the role of elicit-clarify in the event that the current speaker had made submissions that were not very clear and to which the Speaker may then be asking for clarification of the speaker's position. In contrast, questions asked by the current speaker in his contribution in utterance 2; (e.g., Why did they pay them N10 million and for how long? Are we 
sure that he is not getting back to the permanent secretary?) function differently from those of the Speaker; they are more of rhetorical questions to which no overt response is required. However, they are questions meant to probe for further information that will assist in establishing the veracity of the issues on the floor of the House in a manner that will help the members to make an informed decision. Within the context of the member's contribution, it serves as backings for the argument being presented by the member and certainly will provide further grounds for the argument to be established. The response to utterance 1 certainly has the structural role of the second pair part of the adjacency pair initiated by 1 .

\subsection{Elicit-clarify Interrogative Utterances}

In the debate discursive format of legislative discourse, accuracy and facts are sacrosanct as they form the basis of sound legislation. To achieve this, questions are often put by the Speaker at various stages of the debate to get the accurate position adopted by the House or an individual on any particular issue. Elicit-clarify questions prospect a clarification of the preceding utterance or utterances. They can be realized by wh-interrogatives or a high key repetition of a word or phrase in the preceding utterance. For example,

Member: Mr. Chairman, sir, the House would like to know the position of the purported writer of that letter in the Ministry. (3)

Chairman: Why? (4)

Member: The reason being that we expect at least a Permanent/Secretary or somebody in the hierarchy in that Ministry to have written such a letter. (5)

Member: On point of observation, sir (6)

Mr. Speaker: What is your observation about? (7)

Member: Mr. Speaker, sir. Our concern mostly is on implementation... (8)

Member: Mr. Speaker, under Presentation of Report, on page 405.8, the words should read: Local government Administration. The word "Administration" is missing after the word Governments in line 1. (9)

Mr. Speaker: Local government Administration? Let me get that clear. I do not understand what you mean.

Utterances 4 and 7 elicit-clarify questions come in the form of wh-interrogative utterances whose focus is the clarification of propositions expressed in the preceding utterances. Why in 4 prospects a justification for the inquiry raised in the member's earlier utterance (3); which is then provided in the succeeding response (5) to the question. Similarly, Mr. Speaker's utterance 7 elicits clarification from the member who raised a point of observation (6). Utterance 7 has the effect, "could you restate the point more clearly?" Clarifications are necessary to avoid any sort of ambiguity that can impact negatively on the enactment of good laws and ultimately affect the welfare of the people. In 10, the high key repetition of the phrase "Local Government Administration" signals the need for the member who made the contribution (9) to clarify his position. In addition, the elicit-clarify status of the utterance is further underscored by the parenthetical expressions that follow the question; "let me get that clear" and the declarative "I do not understand what you mean."

It should be realized that the goal of elicit-clarify questions is not just a repetition of what has earlier been stated, rather it is the clarification of the point of the utterance that is required. Elicit-clarify questions in LID help crystallize points being made by participants thereby avoiding generalizations or vagueness that could impinge on the value of laws being passed by the House, and consequently making it open to ambiguous interpretation and manipulation.

\subsection{Elicit-confirm Interrogative Utterances}

Elicit-confirm interrogatives constitute another category of questions which invite the addressee to confirm the assumption contained in a speaker's utterance. Generally speaking, the function of the interrogative is to initiate a move that will give or assert agreement with the speaker's assumption. Let us examine the following extract,

The Chairman: The honorable member for Lagos Island I (11)

Please let us listen to suggested amendments. (12)

You want me to remind you of what you said? (13)

AlhajiSann: I could remember briefly. (14)

The Chairman: I think it is there in the Bill that we delete section 30. (15) 
AlhajiSann: We are saying 30(1), (2) and (3) $\neq(16)$

The Chairman: Is that not what you have in the Bill before the House? (17)

AlhajiSann: Especially subsections (1) and (2). What we are saying is if it... i.e. section 30 is as it is now, let us look at 30 (3), which says: "The secretary shall declare his assets and liabilities as prescribed by the code of conduct for public officers." We cannot remove it because it is a constitutional provision. (18)

The Chairman: All right. (19)

Utterances 13 and 17 could be re-phrased as tag questions; (i.e. "You want me to remind you of what you said, don't you?") where the addressee would simply be required to respond with a "yes/no". Utterance 13 assumes that the addressee might have forgotten the suggested amendments to the Bill before the House, hence the suggestion for a reminder. Interestingly, the addressee's response denies the assumption. On the other hand, utterance 17 assumes that the House had already considered certain amendments with regard to the Bill before it; it consequently makes a move to seek confirmation of what the House had already considered. The Speaker's move in 19 "All right" validates the information supplied by the speaker confirming the Chairman's assumption. In the next extract, the majority leader is requested to confirm the assumption that the budgetary allocation contained in the Appropriation Bill is insufficient.

Mr. Speaker: The majority leader, are you taking it as read that the amount appropriated in the Appropriation Bill of 2003 is insufficient because you said you have gone through it? (20)

Majority leader: That's what I'm saying sir, I have gone through it and this Bill would not have been sent to us if the amount is sufficient. (21)

The confirmation sought by the Speaker's question is encoded in the use of the demonstrative pronoun "that" serving as a proform indexing the proposition "the Appropriation Bill of 2003 is insufficient." It establishes a tie with the proposition through a backward reference, thereby affirming the suggestion of insufficiency which the majority leader further reinforced in the expression "this Bill would not have been sent to us if the amount have is sufficient." It should be noted that one reason for such confirmation is that the process of law making neither allows generalizations not backed up by facts nor could accommodate vagueness or ambiguity in members' contributions.

\subsection{Elicit-agree Interrogative Utterances}

This sub-category of elicitation utterances invites the addressee to agree with the assumptions raised by the speaker that the proposition expressed is self-evidently clear. Elicit-agree questions provide leads that are quite useful as a way of achieving consensus among members on any issue before the House. Sometimes a speaker could use elicit-questions, such as "are you with me?" or "don't you agree with me?" as a way of obtaining concurrence from a listener thereby serving as a booster for the speaker to continue with his/her contribution. The response to elicit-agree questions may simply be yes (concurrence) or no (denial of the assumption). The following extracts demonstrate the use of elicit-agree questions.

Chairman: Honorable members, I believe you all have this Bill that we are referring to before us. (22)

Members: (chorus) Yes sir. (23)

Alh. Bura: Mr. Speaker, sir, I want to refer to page 404, under absent excused. I do not know why my name should be there. I was only late to the Session on that day, and not absent. (24)

Mr. Speaker: Okay, you want to be moved up? (Laughter) (25)

Alh. Bura: Yes, sir. (26)

The extracts above show positive responses, yes sir, to the interrogative acts contained in the indirect question 22 and the direct question in 25 , thus underscoring the agreement of the respondent with the evidently clear proposition in the moves that initiate the responses. In utterance 22 , for example, the proposition contained in indirect interrogative act makes it evidently clear that copies of the Bill had earlier been distributed to the members as part of their resources for the proceedings of that legislative day. The indirectness of the question underscores the almost redundant nature of the question. The same can be said of the positive response to the Speaker's question in utterance 25 where the illocutionary force of the interrogative is unmistakable: where the Speaker's laughter constitutes not only an indication of the Speaker's awareness of the intention of the member (Alhaji Bura) who raised the request but also serves as a tacit agreement with the member's request. The 
question, "okay, you want to be moved up" could, therefore, be regarded as a mere formality once the laughter itself can be interpreted as concurrence.

\subsection{Elicit-permit Interrogative Utterances}

Elicit-permit questions in LID request the Speaker to grant permission to the utterer to take a solicited action. For instance, when there arises the need for a speaker to refer to the statute books, cite a portion of either the standing rules of procedure of the House or the Constitution of the Federal Republic of Nigeria, or makes reference to any material that is needed as backings for the argument being presented by the speaker. The Speaker may grant or refuse the request. Once granted the speaker proceeds to carry out the action for which permission is granted. This is the case in the following extract,

Mr. Oyew: Mr. Speaker, sir. The issue that I am raising this afternoon is of urgent public importance... (27)

Mr. Speaker: Honorable member for AmuwoOdofin, before you proceed “Can you go to Order 41?" (28)

Mr. Oyew: Mr. Speaker, sir. My own copy is not here with me. (29)

Mr. Speaker: Somebody will oblige you. (30)

Mr. Oyew: Mr. Speaker, sir. Festac town is a residential estate, what happened there is unprecedented... The pictures of the incident were taken. Can I present the pictures, sir? (31)

Mr. Speaker: I have seen those pictures before. (32)

The speaker seeks permission (31) to present the pictures to the whole House as a form of evidence to buttress his argument. It must be noted that the use of the modal verb "can" does not imply "ability" rather it implies a request for permission. Elicit-permit questions, such as used here, usually feature in forensic discourse.

\section{Interrogative Utterances as Directives}

When utterances with interrogative form serve as directives, they prospect an interactional action rather than just a verbal response from the addressee. In the context of the LID, directives are usually issued by the Speaker either as a turn allocation cue (Ayodele, 2010) or for a current speaker to take a particular action at a point in the flow of talk. Generally, elicit-direct questions fall into two broad categories; inclusive and non-inclusive directives. Inclusive interrogative utterances have the entire membership of the House as its focus. In other words, it is expected that the response to the directive would come from the entire membership collectively. For example, the following extracts show that the utterance is directed at all the membership present at that particular sitting of the House.

Mr. Speaker: Good morning, Honorable members. You're welcome to this sitting of Monday, 3rd June, 2002. Shall we quickly go through the Votes and Proceedings for Thursday, 30th May, 2002 ? (33)

Members: $\varnothing$ (no verbal response, but members were going through the documents before them) (34)

Mr. Speaker: That is a two-legged prayer. Who is seconding? (35)

Alh. Obas: Mr. Speaker, sir. I rise to second the motion as moved by the majority leader. (36)

Mr. Speaker: Honorable members, that is the application. Can I have members' contribution? (37)

Mr. Oyew: Mr. Speaker, sir. The issue that I am raising this afternoon is of urgent public importance... (38)

Mr. Speaker: Honorable member for AmuwoOdofin, before you proceed “Can you go to Order 41?" (39)

The interrogative utterances in these extracts can be interpreted as directives to which all the members of the House (in 33 and 35) and the particular speaker (Mr. Oyew) are expected to respond in action. Structurally questions often used by the Speaker implying a directive act, are characterized by subject-operator inversion, May + request, and the wh- questions. In those characterized by subject-operator inversion requiring largely a yes/no answer, the modal auxiliaries, "shall" and "can" occupy the initial position followed by the first person pronoun "we" and "I". For example, in "Shall we quickly go through the Votes and Proceedings for Thursday, 30th May, 2002" the "we" is inclusive of both the Speaker (who raised the question) and other members present in the House. In a similar way, "Can I have members' contribution?" throws open the floor to all the members; the turn is then allocated by the Speaker to the next speaker on the basis of first come first served. "Can you go to Order 41?" in 39 is a directive to the addressee to take an action of turning to the Rules of Procedure of the 
House. When used in this way, "can" does not require a verbal response, rather the addressee is expected to agree with the suggestion and then comply with the directive.

The May + request and wh- interrogative utterances $(40,43,44)$ are generally perceived as directives eliciting actions rather than mere information as responses. Though such questions are sometimes open-ended, and are actually not directed at any particular person, they are understood as meant for a particular person (usually the majority leader) or the honorable members collectively, within the context of use.

Questions characterised by subject-operator inversion elicit information. Since questions generally constitute the first pair part of an adjacency pair, the second pair part automatically comes as a response from the next speaker whose selection might have been explicit or implied. The following extracts demonstrate the point.

Mr. Speaker: To enable us take that, may I request for a motion from the majority leader? (40)

Mr. Speaker: Is anyone opposed to that? (41)

Members: No. (the sound of "no" reverberates) (42)

Mr. Speaker: So, may I have a motion to that effect? (43)

Mr. Speaker: He next item on the Order paper for today is the presentation of the Report of the House committee on Local Government Administration on the crisis at Epe Local Government area of Lagos State. May I get the application to resolve into the Committee of the whole to enable us take that presentation? (44)

Mr. Speaker: Thank you. Having done that, who is seconding? (45)

Mr. Speaker: That is okay. Who is seconding the motion as moved by the Majority Leader? (46)

Utterances 40, 43 and 44 reveal the use of the request format in signaling that the floor is open to the next speaker. As further revealed, though the Speaker might not have selected any member in particular through this format, it is taken for granted that following the House procedures, the majority leader or any other official functioning in the capacity of a leader at any sitting would be impliedly selected. This question format is often associated with the local acts of moving motions and they are exclusively used by the Speaker (at plenary sessions) or the Chairman at the committee of the whole House.

The various discourse roles of interrogative utterances in legislative discourse can be summarized as follows.

Discourse Function of Questions in LID

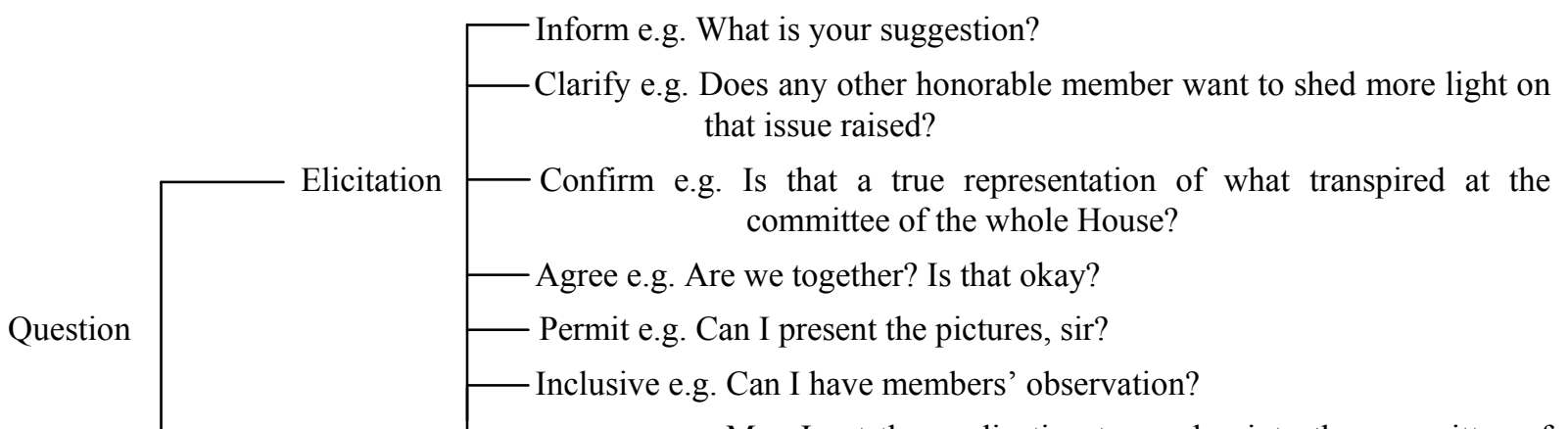

May I get the application to resolve into the committee of the whole House?

Directive Who is seconding the motion?

Non-inclusive e.g. Hon. Member for Alim I, Can you go to Order 40? / May I request for a motion from the majority leader?

\section{Conclusion}

The various functional categories of interrogative utterances in legislative interactional discourse constitute a vital linguistic member resource required to enhance the effectiveness of legislators in the performance of their legislative duties. In presiding over legislative sessions, the Speaker, exercises control over the general conduct of the business of the House through verbal means. To a large extent, he deploys interrogative utterances to give direction and regulate and direct the contribution of members to any motion on the floor of the House. This ensures the smooth flow of talk. Similarly, it has been demonstrated that the various categories of elicitation 
interrogative utterances assist topical development through confirmation and classification. In addition, members' political and sometimes ideological posture could be accessed through their responses to such interrogatives that seek to make them agree or disagree, support or oppose a motion on the floor. Since the main activity of a legislature is deliberative, there obviously is the need for detailed information that will assist the House to arrive at an informed and enlightened decision. One way to achieve this goal would be through posing questions that will elicit information. The category of questions referred to as elicitation prospects informative verbal responses from their respondents. On the other hand, directive interrogatives, generally exclusively used by the Speaker, serve as a vital tool to direct the conduct of debates on the floor of the House. In other words, they have discursive and organizational roles in legislative discourse. They are often used by the Speaker to issue instructions to other members of the House not only to take an upcoming speaking turn but also to take verbal action at the point in the talk flow where they are expected to make a contribution. Based on the foregoing, it could therefore be asserted that interrogative utterances in legislative interactional discourse perform discursive roles that are crucial to propositional progression and coherence. It is expected that an understanding of the discourse functions of these interrogative utterances and their skillful deployment by the legislators would enhance the process and the quality of law making in the Nigerian legislature.

\section{References}

Austin, J. L. (1962). How to do things with words. Oxford, Oxford University Press.

Ayodele, A. O. (2010). Conversational strategies in Legislative discourse in Lagos and Ogun State Houses of Assembly in Nigeria. Unpublished Ph.D Thesis. University of Ibadan.

Ayoola, A. (2008). A discourse analysis of select proceedings of the Ogun State House of Assembly. Unpublished M.A. dissertation. University of Ibadan.

Bach, H., \& Harnish, R. (1979). Linguistic communication and speech acts. Cambridge, Mass: M.I.T. Press.

Balogun, T. A. (2011). Interrogative Questions as Device for the Representation of Power in Selected Texts of AkachiAdimora-Ezeigbo. The Journal of Pan African Studies, 4(8), 40-58.

Burton, D. (1980). Dialogue and discourse. London: Routledge and Kegan Paul.

Carbo, T. (1992). Towards an interpretation of interruptions in Mexican parliamentary discourse. Discourse and Society, 3(1), 25-45. http://dx.doi.org/10.1177/0957926592003001002

Chilton, P. (2004). Analysing political discourse: Theory and practice. Oxon: Routledge.

Huddleston, R. (1984). Introduction to the grammar of English. Cambridge: Cambridge University Press. http://dx.doi.org/10.1017/CBO9781139165785

Ilie, C. (2000). Cliché-based metadiscursive argumentation in the Houses of parliament. International Journal of Applied Linguistics, 10(1), 65-84. http://dx.doi.org/10.1111/j.1473-4192.2000.tb00140.x

Jakobovits, L. A. (1969). Rhetoric and stylistics: some basic issues in the analysis of discourse. College Composition and Communication, 20, 314-328. http://dx.doi.org/10.2307/355035

Lyons, J. (1977). Semantics (Vol. 1 \& 2). London: Cambridge University Press.

Martin, J. \& Rose, D. (2003).Working with Discourse: Meaning beyond the clause. London and New York: Continuum.

Mey, J. (2001). Pragmatics: an introduction. United Kingdom: Blackwell.

Oyeleye, A. L. (2004). The power of words and the techniques of public communication. In Lekan Oyeleye (Ed.), Language and Discourse in Society (pp. 168-178). Ibadan: Hope Publication.

Quirk, R., Greenbaum, S., Leech, G., \& Svartvik, J. (1972). A grammar of contemporary English. London: Longman.

Sadock, J. (1974). Towards a linguistic theory of speech acts. New York: Academic Press.

Sinclair, J. M., \& Coulthard, M. (1975). Towards an analysis of discourse. Oxford: Oxford University Press.

Sinclair, J. M. (1972). A course in spoken English grammar. London: Oxford University Press.

Steiner, J. (2004). Deliberative politics in action: Analysing parliamentary discourse. New York: Cambridge University Press. 
Tsui, A. B. (1991). Sequencing rules and coherence in discourse. Journal of Pragmatics, 15(2), $111-129$. http://dx.doi.org/10.1016/0378-2166(91)90056-4

Van Dijk. (2000). Parliamentary discourse. In R. Wodak, \& T. A. Van Dijk (Eds.), Racism at The Top: Parliamentary Discourses on Ethnic Issues in Six European States (pp. 45-78). Klangenfurt, Austria: Drava Kerlag.

Van Dijk. (2003). Knowledge in parliamentary debates. Journal of Language and Politics, 2(1), 93-129. http://dx.doi.org/10.1075/jlp.2.1.06dij

Van Dijk. (2004). Text and context of parliamentary debates. In Paul Bayley (Ed.), Cross Cultural Perspectives on Parliamentary Discourse (pp. 339-372). Amsterdam: Benjamins. 